\title{
Sight: The Last Bastion Of The Brick And Morter Retailer To Survive?
}

Corinne Nell, University of South Africa (UNISA), South Africa Jan Wiid, University of South Africa (UNISA), South Africa

\begin{abstract}
The physical brick and mortar retail environment has been the bastion of survival for retailers over the years. With the developments in technology and the changing shopping patterns of consumers, apparel retailers are facing competition from alternative channels, such as the internet where consumers browse, compare and ultimately purchase products. Faced with this evolution, it has become critical for brick and mortar retailers to reconsider the principles and practices of in-store consumer engagement. They need to understand how their physical in-store environments can be used optimally in order to ensure sales optimisation, consumer satisfaction and sustainable profitability.This state of affairs has led to this study, which focuses on sight and its influence on consumers' buying behaviour. The primary research question that was posed in this study was to explore the influence of sight on consumers' buying behaviour in apparel retail stores. The type of research design used in this study was exploratory in nature, making use of a qualitative approach and a communicative technique of focus group interviews and naïve sketches. The data gathered was analysed by means of Tesch's inductive descriptive coding technique, better known as thematic analysis. It was found that sight has the ability to influence consumers in either a subconscious or a conscious way. This has a direct influence on the amount of time that consumers will spend in-store and ultimately influence their buying decisions and behaviour, either positively or negatively.
\end{abstract}

Keywords: Store Atmospherics; Senses; Sight; Consumer Behaviour; Approach Behaviour; Avoidance Behaviour

\section{INTRODUCTION AND OBJECTIVES}

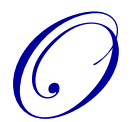

ver the past few decades, the retail industry has grown exponentially, resulting in a highly intensive and competitive market (Wanninayake \& Randiwela, 2007, p. 2; Liaw, 2007, p. 1) and further resulting in retailers not being able to rely only on their products, prices, promotions and place for survival and growth (Liaw, 2007, p. 1; Wanninayake \& Randiwela, 2007, p. 5). It is becoming more and more important for retailers to use store space more effectively in order to differentiate themselves from competitors and, in doing so, to provide consumers with a pleasant shopping experience.

In their studies, Spies, Hesse and Loesch (1997, p. 1) pointed out that irrespective of the specific merchandise being offered, some stores are more attractive than others and, ultimately, more profitable. Some stores provoke a feeling of happiness and well-being among consumers, which results in a more positive inclination to buy, while other stores can easily provoke a feeling of irritation, which causes a resistance to buy. Consequently, it is essential for retail stores to create a positive in-store environment as a positive mood can easily increase the consumers' time and money spent (Spies et al., 1997, p. 1).

A positive and pleasurable in-store environment can be created by focusing on various elements such as music, scent, lighting, colours and floor covering that excite the senses of shoppers (Berman \& Evans, 1998, p. 552). According to ACP Connections (n.d., p. 1), 83 percent of all in-store communications appeal to one sense - the eyes or sight - while the rest (17\%) are left to cater to the other four senses. It has also been found that most retailers use only sight as a sense to attract consumers into their stores, emphasising the importance attached to this sense (ACP Connections, n.d., p. 1). 
This study aimed to obtain a holistic view of factors impacting on store atmospherics and, more specifically, sight, which is becoming more and more of importance to brick and mortar retailers in their fight for consumer patronage. A consumer-centred response approach was followed. The study could benefit apparel retailers in their quest to stay competitive in the face of digital competition and changing consumer buying patterns. The same findings can pragmatically be applied to apparel retailers worldwide, with only minor adjustments to cater to local conditions and customs.

This study aims to explore, within the context of Tshwane's apparel retail stores, the influence of sight on consumers' buying behaviour.

The following section gives an overview of store atmospherics, what it is, the sense of sight, and consumers' buying behaviour. The empirical findings and discussion of the findings appear in the latter part of the paper.

\section{DISCUSSION}

\section{Store Atmospherics}

The aim of any retail store's design is to enhance the consumers' shopping experience, to differentiate itself from competitors, and to enhance in-store traffic, thus leading to consumer expenditure (Pradhan, 2007, p. 347). A method to achieve this aim is through the creation of store "atmospherics" - a term first introduced by Phillip Kotler (Pradhan, 2007, p. 347). It is a word used by retailers to describe elements such as lighting, colour, music, aromas and so forth, that appeal to the five human senses and that contribute to the overall in-store environment and experience (Bell \& Ternus, 2006, p. 21). Bell and Ternus (2006, p. 21) are of the opinion that atmospheric elements have the ability to influence consumers' feelings about being in, and staying in, a retail store and that the longer consumers stay in a store, the more likely they are to buy.

The term "atmosphere" or "atmospherics" can be defined as the physical characteristics of a store that are used to develop an image in order to attract consumers (Berman \& Evans, 2010, p. 508). Liu and Jang (2009, p. 495) defined atmospherics as ".. the conscious designing of space to produce specific emotional effects in buyers that enhance their purchase probability." Levy, Weitz, and Beitelspacher (2012, p. 490) describe atmospherics as the design of a store's environment by appealing to the five human senses. It is argued that retail stores have come to realise that developing atmospheric elements that complement other aspects of the store, such as the store design and merchandise, is more advantageous to the store in the long run (Levy et al., 2012, p. 490). For the purpose of this study, the definition of store atmospherics proposed by Kotler, is used as the basis for the discussion of this topic. Kotler (2001, p. 50) defines atmospherics as the designing of a buying environment in which specific buying emotions are created through the use of the senses (sight, sound, scent and touch) in order to enhance the consumer's likelihood of purchasing.

A retailer's image depends greatly on its atmosphere - the psychological feeling evoked within consumers the moment they enter a store (Berman \& Evans, 2010, p. 508). Berman and Evans (2010, p. 508), as well as Bell and Ternus (2006, p. 36), maintain that a store's atmosphere has the ability to influence consumers' shopping satisfaction, the physical time spent browsing and evaluating the merchandise, the eagerness of consumers to communicate with store personnel and to make use of store facilities such as dressing rooms, the consumers' willingness to spend more money than originally planned, and the possibility of future patronage. These elements do not only contribute to the overall image of the store, but can also be used as an effective marketing tool to differentiate one store from other stores/competitors, to effectively communicate with their consumers, and to attract consumers' attention (Kotler, 2001, p. 50).

Based on the comments from various authors, it is clear that the atmosphere of a retail store - and maybe more so for apparel retailers - needs to be managed and strategically used in order to entice consumers to spend more time browsing, and ultimately spending, in a store. Different atmospheric elements can tactically be used to target specific consumers (Gupta \& Randhawa, 2008, p. 225). For the purpose of this study, the store atmospheric element focused on is sight. This is mostly due to the fact that it is regarded as a main tool that retailers can use in their efforts to get consumers to spend more time and money in their store. 


\section{Sight}

Sight refers to the act of seeing and forming a perception of specific things or objects by using the eyes (AR Dictionary, 2010). It is regarded as the most powerful of all the human senses and it is also the most seductive (Hultén, 2011, p. 259). Gobé (2009, p. 259) reports that individuals from the age of ten years and older use sight as the most predominant sense in order to explore, discover, and understand the world. Kotler (2001, p. 51) classifies sight as all those visual elements, such as the colours, lighting, shades, and shapes, that retailers use to create an appealing atmosphere. From this, it can be deduced that what people see in terms of a store's interior and exterior is critical in attracting their attention and their willingness to act upon these impulses (Hultén, Broweus \& Van Dijk, 2009, p. 87).

Kerfoot, Davies, and Ward (2003, p. 145) found that 90 percent of in-store environment cues are taken in through sight due to the fact that many in-store cues in the retail setting are visually communicated. The CEO, founder and owner of the Swedish fashion retailer, 'Gina Tricot', states "... what the eyes see is extremely important... I say that the eyes buy 70 or 80 percent of what people buy" (Hultén et al., 2009, p. 9).

According to Kotler (2001, p. 51), several factors can have an impact on sight, but two that are crucial are colour and lighting which are discussed next.

\section{Colour}

According to Esaak (2012), colour “ “... is the element of art that is produced when light, striking an object, is reflected back to the eye." He further indicated that there are three known and important characteristics of colour. The first is shade, which refers to the name that is given to a colour; for example, red, blue and green. The second characteristic is intensity, which means the strength and brightness of a colour; for example, "royal" blue or a "dull" gray. The last characteristic of colour is the value thereof, which refers to the lightness or darkness of a colour that can change (Esaak, 2012). Retailers need to be aware of these distinctions if they want to optimise the impact of colour on the sight of consumers.

Colour is one of the first things that consumers recognise and is therefore one of the most imperative design instruments used by retailers to communicate to their consumers (Bell \& Ternus, 2006, p. 38). The role and importance of colour is well documented and it has the ability to affect:

- $\quad$ consumers' sight experience, as it can create certain emotions and feelings within consumers that activate and stimulate specific memories, thoughts and experiences (Gobé, 2009, p. 79)

- $\quad$ organisations, brands, logos, products, and even window displays, and it enables a better recall of different brands or products in the future, as well as a better and more accurate understanding of what a specific organisation or brand represents (Gobé, 2009, p. 80)

- different cultures by giving them social meanings (Hultén et al., 2009, p. 97; Morgan, 2008, p. 78; Levy et al., 2012, p. 491); for example, the colour white in China symbolises a period of death and mourning, whereas in Western cultures, it is symbolic of purity. Table 1 provides the meaning of the different colours. 
Table 1: Meaning of Colours

\begin{tabular}{|c|c|}
\hline Colour & Meaning \\
\hline Yellow & $\begin{array}{l}\text { Associated with sunshine and gold, happiness, brightness, friendliness and cheerfulness. It is related to } \\
\text { lemons and daisies, as well as to spring and summer. }\end{array}$ \\
\hline Orange & $\begin{array}{l}\text { Seen as a friendly, kind and sociable colour that is filled with anticipation and excitement. People associate it } \\
\text { with fire and flames, a tropical sea and a sun setting. }\end{array}$ \\
\hline Red & $\begin{array}{l}\text { Associated with words such as exciting, loving, powerful, stimulating and angry. Red normally comes across } \\
\text { as a warm and passionate colour and it is also associated with love, Valentine's Day and Christmas. It } \\
\text { expresses terms such as sales, warnings or fire. }\end{array}$ \\
\hline Pink & $\begin{array}{l}\text { Associated with words such as sweet, loving, pretty, girly, ribbons and lace. It can also be associated with } \\
\text { raw meat, as well as flowers, Mother's Day and lingerie. }\end{array}$ \\
\hline Green & $\begin{array}{l}\text { Associated with being alive and growing, as well as with summer and spring. Bushes, trees, forests, nature } \\
\text { and St. Patrick's Day are related to green. }\end{array}$ \\
\hline Blue & $\begin{array}{l}\text { Most people's favourite colour and is associated with pureness, coolness and calmness, as well as with soft } \\
\text { woollen skies, gentle horizons, the ocean and loyalty. It is a quiet colour, but it can become moody or even } \\
\text { depressing. }\end{array}$ \\
\hline Blue-Green & $\begin{array}{l}\text { Can be described as cool, tasteful and alive, but it can also be a sensitive colour. It is associated with water, } \\
\text { sky and grass and it is a very effective summer colour. }\end{array}$ \\
\hline Peach & $\begin{array}{l}\text { A "toned down" colour from orange and suggests warmth and happiness. This is a pretty and comfortable } \\
\text { colour - easy to be with and pleasant to be in. }\end{array}$ \\
\hline Rust & $\begin{array}{l}\text { Derived from orange, but has a deep, rich and earthy shade with none of the obvious "bright" qualities of } \\
\text { orange. It is an earthy colour that easily fits in with other colours and it is normally related to autumn. }\end{array}$ \\
\hline Violet/Purple & $\begin{array}{l}\text { Associated with happiness and youthfulness, as well as with taste, judgement and distinction. Purple is a high } \\
\text { fashion colour and one that is normally worn by kings, queens and members of the court. }\end{array}$ \\
\hline Grey & $\begin{array}{l}\text { Known for making separations, but no statements. Grey goes very well with other colours that are more } \\
\text { vibrant and it is associated with being depressed or it can be a very elegant and sophisticated colour - } \\
\text { depending on how it has been used. }\end{array}$ \\
\hline Brown & $\begin{array}{l}\text { Associated with the earth, a farm or a home, and with things such as clay, wood or any other natural } \\
\text { material. It is a warm, relaxed colour which is related to autumn and it has the ability to complement other } \\
\text { colours without disappearing. }\end{array}$ \\
\hline White & $\begin{array}{l}\text { A strong, as well as supporting colour that makes every other colour bigger, brighter and bolder. It is } \\
\text { associated with innocence, hope, angels and pureness. }\end{array}$ \\
\hline Black & $\begin{array}{l}\text { Associated with the night, darkness, death, funerals, depression and mystery. It is also a colour of } \\
\text { sophistication and elegance that can easily fit in with other colours. }\end{array}$ \\
\hline
\end{tabular}
Source: Adapted from Pegler (2010, pp. 9-10); Bell and Ternus (2006, p. 38)

Retailers need to be aware of the associations that consumers make with certain colours and factor this in with their marketing actions.

Table 2 clearly indicates that colour can directly influence consumers' acts in a certain way. For instance, some colours can make consumers feel warm, friendly, big-hearted and responsive enough in order to buy. Other colours will make consumers feel cold, unfriendly, unresponsive, moody and impossible to reach. Table 2 further indicates that some colours share more or less the same types of characteristics and can therefore be grouped into three ambiguous, but convenient, groups (Pegler, 2010, pp. 9-10).

Table 2: Colour Groupings

\begin{tabular}{|l|l|}
\hline \multicolumn{1}{|c|}{ Colours } & \multicolumn{1}{c|}{ Meaning } \\
\hline $\begin{array}{l}\text { Warm Colours - Red, orange, yellow, } \\
\text { pink, rust, brown, gold and peach }\end{array}$ & $\begin{array}{l}\text { Warm, aggressive, spirited, advancing colours. Also known to be emotional, vibrant } \\
\text { and hot, and it is used to stimulate active responses. }\end{array}$ \\
\hline $\begin{array}{l}\text { Cool Colours - White, blue, green, } \\
\text { violet and blue-green }\end{array}$ & $\begin{array}{l}\text { Cool and receding colours. Also known to have a peaceful, gentle and calming } \\
\text { effect. }\end{array}$ \\
\hline $\begin{array}{l}\text { Neutral Colours - White, grey, black } \\
\text { and brown }\end{array}$ & $\begin{array}{l}\text { Neutrals can either be warm or cool. Black, white and all the shades of grey are } \\
\text { considered cool, while anything from off-white through all the shades of beige to } \\
\text { the deepest brown is called a warm neutral. }\end{array}$ \\
\hline
\end{tabular}

Source: Adapted from Pegler (2010, pp. 9-10); Bell and Ternus (2006, p. 38); Levy et al. (2012, p. 491)

It is therefore important for retailers to know and understand the history and psychological meaning behind colours, the possible connotations that consumers can have with it, and their potential reactions to it. This will help 
them to create a pleasant in-store atmosphere that will stimulate positive emotions within consumers, thus motivating them to make a purchasing decision (Pegler, 2010, p. 8; Gobé, 2009, p. 81).

\section{Lighting}

As stated, lighting impacts on colour and therefore impacts on the consumer. Kotler (2001, p. 51) defines lighting as "... the medium of illumination that makes sight possible" (Collins, 2012). It simply means that both artificial and natural light sources can be used in order to make objects, figures, pictures and so forth visible, appealing and attractive, as all colours depend on some form of lighting (Eicar, n.d.; The Free Dictionary, 2012).

Without the use of proper lighting, colour cannot be as effective as it is intended to be. It is through the use of light that things/objects become visible. Therefore, all types of colours depend greatly on the use of lighting (Pegler, 2010, p. 25). According to Hultén et al. (2009, p. 99), appropriate lighting has the ability to create an appropriate mood, which, in itself, attracts and captures the consumer's interest. Hultén et al. (2009, p. 99); Pegler, (2010, p. 25) and Levy et al., (2012, p. 490) have also identified several reasons why lighting is important:

- It offers apparel retailers the opportunity of variation, meaning that it enables them to create a different instore scene/atmosphere from time to time (Hultén et al., 2009, p. 99). For example, an athletics store uses different lighting colours to reflect the seasons, such as green lighting for spring.

- It is an important element in a retail store's inner and outer design because it can create a favourable impression of all the merchandise on offer and display, which ultimately contributes to the store's atmosphere (Gupta \& Randhawa, 2008, p. 225).

- It has the ability to highlight merchandise, to separate one area from another, to form space and to create a mood or a feeling that can enhance the store's overall image (Levy et al., 2012, p. 490).

- It has the ability to guide consumers into a store, as well as through it, by moving their attention from one feature area to another (Pegler, 2010, p. 28).

- It is an important factor that can contribute to the overall atmosphere of the store, especially when a specific mood needs to be created, such as warm, cosy or romantic, or even just to put consumers in a specific mind set (Levy et al., 2012, p. 491).

From the above, it can be inferred that lighting plays a critical role in the creation of an effective in-store atmosphere. It is therefore important for retailers to know and understand the importance and effective uses of lighting in the creation of an atmosphere that is conducive to a positive consumer experience (Binggeli, 2010, p. 306). Retailers should keep in mind that the type of lighting used must at all times focus on and complement good colour, creating contrasts and balance (Binggeli, 2010, p. 306).

It is clear from the above discussion that sight does have an influence on consumers' emotions in one way or another which can later result in a specific behavioural response (Jang \& Namkung, 2009, p. 451; Kang et al., 2011, p. 2). The influences that sight (atmospheric element) might have on consumers' emotions are discussed in the next section.

\section{Consumer Emotions and Buying Behaviour}

According to Mehrabian and Russell (1974), in-store environmental stimuli, such as the human sense and sight, have a direct influence on consumers' emotions, which further results in a behavioural response (Jang \& Namkung, 2009, p. 451; Kang et al., 2011, p. 2). From the literature, it can be seen that the human senses do have an influence on consumers' emotions. The moment that consumers see a specific picture or object, past memories are immediately recalled and re-experienced and therefore specific emotion, such as happy or sad, is brought to the consumers' mind (Hultén et al., 2009, p. 10, 57, 115).

Liao and Liaw (n.d., p. 2) define emotions as the “... oral expression of feelings and as a personal, subjective psychological state." A store's environment can elicit three types of emotions. The first is pleasure, which can be described as an effectual reaction and will indicate whether or not consumers find the environment enjoyable (Jang \& Namkung, 2009, p. 451). The second emotion is arousal, which indicates how much the environment stimulates the consumers. The third emotion is dominance, which is concerned with whether or not consumers feel in control in the 
environment. Jang and Namkung (2009, p. 451), however, indicate that dominance has a non-significant effect on behaviour.

It is likely that certain positive emotional reactions caused by the sense, sight, will result in increased consumer spending, but it will highly depend on the type of in-store atmosphere that is created (Kotler, 2001, p. 54). Therefore, it can be inferred that emotional reactions (pleasure, arousal and dominance) will most likely have an influence on consumers' behavioural responses. Furthermore, Mehrabian and Russell (1974) defined the emotional state and behavioural responses of consumers' to an environment as approach (positive) and avoidance (negative). Approach behaviours include all positive behavioural intentions that are influenced by an environment, such as good lighting, pleasant music and attractive smells, whereas avoidance behaviours are the opposite, which include all the negative behavioural intentions (Kang et al., 2011, p. 3).

It can be concluded from the above literature review that in-store atmospheric elements, including sight, do have an influence on the emotions of consumers and will further influence their buying behaviour. The next section deals with the research methodology and the findings of the research.

\section{RESEARCH METHODOLOGY}

Qualitative research was used for this study, as a detailed explanation of sight and its influence on consumers' buying behaviour was needed, as well as the fact that qualitative research has the ability to discover true significance and new insights about the available data (Zikmund \& Babin, 2010).

The extent to which sight influences consumers' buying behaviour was studied by means of exploratory research which is used to explore and to clarify ambiguous situations and ideas of a research problem (Zikmund and Babin, 2007, p. 42).

Due to the exploratory nature of the study - non-probability - purposive sampling was used. Nonprobability sampling is a method where the samples are grouped in a process that does not give all the individuals in the population an equal chance of being selected (Tustin et al., 2005). Subjects in a non-probability sample are usually selected on the basis of convenience, as they are easy and/or inexpensive to reach, or by the purposive personal judgment of the researcher (Hair, Bush \& Ortinau, 2009, p. 312). In purposive sampling, the researcher samples with a purpose in mind (Zikmund \& Babin, 2010).

The inclusion criteria for the purposive sampling for this research study were as follows:

- $\quad$ Any male or female older than 18 years

- $\quad$ Any person who bought at apparel retail stores

- $\quad$ Any person who resided in the Tshwane region of Gauteng

- $\quad$ Any person that could understand, speak and write English

Data were collected by means of a communicative technique of interviews, and the selected methods were focus group interviews and naïve sketches. Focus group interviews which are unstructured, free flowing interviews with small groups of people - generally eight to 12 participants, and naïve sketches, which are open-ended questionnaires that ask participants questions regarding the specific topic (Hair et al., 2009, p. 161), were used to collect data from 16 participants (eight in each focus group and naïve sketch). Due to this, two forms of data was received and compared with one another in order to gain maximum data from each participant.

The focus groups were based on the use of visual material in order to create an atmosphere. The photographs were taken of the atmospheric themes implemented by two stores in the Tshwane region and they were included in both the naïve sketches and the focus groups. The participants were asked two questions (the same questions in both the naïve sketch and focus group interview) which were derived from the research objectives:

- What do you understand about a clothing retail store's atmosphere?

- When you walk into a clothing store, what is the influence of the colours and lighting (what you can see) used in-store on your buying behaviour? 
Thematic analysis was used since the required data for this research study was contextual in nature. Thematic analysis is a qualitative research process that involves intensive searching through data to identify any possible patterns - known as themes and categories that might occur more than once (Tesch, 1990, p. 113). It is a process that organises and describes data in detail (Braun \& Clarke, 2006).

\section{RESULTS}

The outcomes of the questions asked in both the focus group interviews and the naïve sketches are examined in terms of three main themes and their underlying categories as outlined by Tesch's model (thematic analysis).

Theme 1: Participants display a good understanding and awareness of store atmospherics, the "general ambiance," it creates and the variety of "controllable elements" used to do so, as well as the potential it has to influence their moods and in turn their buying behaviour.

Participants identified a store's atmosphere as consisting of a variety of controllable elements, such as lighting, music, layout, decor, temperature, smell and staff attitude, all of which create the general ambience. It was highlighted that the general ambience of a store is important as it creates a general feeling of either being welcome, or not, the moment a person enters a store.

The participants also indicated that store atmospherics potentially influenced their mood and, in turn, their buying behaviour. In the focus group discussion, it was found that if a store managed to use the controllable elements of lighting and colours correctly, the likelihood of the participants' buying increased. However, if these controllable characteristics were used incorrectly, the likelihood that participants would rather leave a store was enhanced.

Two categories emerged from the first theme and are explained below.

Category 1: A store's atmosphere consists of a variety of controllable elements, such as lighting, music, layout, decor, temperature, smell and staff attitude, all of which create the general ambience.

From both the focus group interviews and naïve sketches, it was clear that the participants understood the term "store atmospherics" (as defined in the literature) as the controllable elements that a store can use to create a general ambience or feeling. General ambience is defined by Dunne and Lusch $(2008$, p. 457) as the "overall feeling or mood projected by a store through its aesthetic appeal to human senses." The participants indicated that a pleasant in-store environment was created through attention to detail. They further indicated that store atmospherics could be anything that affected the senses of consumers, such as sight, sound, smell and touch, and that it was important for the in-store temperature to be comfortable. They felt that it should be too cold rather than too hot.

The following quotes of the participants were taken from both the focus group interviews and naïve sketches to confirm the findings regarding the first category of controllable elements:

- “... it's mostly all controllable elements that lead to our likes, it's like the type of music that is playing in the background, the colours, the lighting, the scent that you get when you walk into the store, is something that retail can control ..."

- "The 'general ambiance' of the store created by lighting, music, layout, availability of personnel and paypoints."

- “... includes mostly all the controllable characteristics that a store utilises in order to entice the customer and influence their moods."

Category 2: Store atmospherics potentially influenced their mood, and in turn their buying behaviour.

The participants from both the focus group interviews and naïve sketches felt that if the lighting of a store was sufficient, it highlighted the merchandise displays. This enticed the participants to further explore (positive 
influence on mood) the store offerings and that might influence the time spent in-store and in turn influence their buying behaviour. The participants further pointed out that they got irritated when they could not see what was going on in the store and that the type of lighting in a store influenced their buying behaviour, depending on what they were looking for. Three quotes were taken from both the focus group interviews and naïve sketches to validate the findings:

- $\quad$ "I would say if the displays are done properly with proper lighting on it, it will highlight the product and you would walk in and say, 'That looks nice!' and you walk in to go and see what there is and so, yes, definitely I would say it does." [influence your buying behaviour or how long you stay in a store]

- "... lighting influences my buying behaviour, depending on what type of clothes I am looking to buy."

- $\quad$ "... if a store is badly lit or the colours are, for example, shocking and bright, I will soon get irritated which will make shorten my time spend in that store."

Theme 2: Store atmospherics speaks a "silent language" to participants, reinforcing niche/target market appeal and/or merchandise integrity/quality, or lack thereof, either enticing them into or repelling them from a store.

Participants from both the focus group interviews and naïve sketches were of the opinion that store atmospherics spoke a silent language, meaning that the participants did not always recognise the atmospheric elements used in-store, but if they were unpleasant (lighting too dark), they immediately became aware of it or noticed it. It can therefore be implied that store atmospherics has a subliminal (subconscious) influence on consumers.

The participants further pointed out, in both the focus group interviews and naïve sketches, that store atmospherics could be context driven and therefore appeal to a specific target market or consumer group. The participants said that they would not enter some stores, because they did not feel comfortable in there and these stores did not fit in with their style and personality.

The participants also indicated that store atmospherics formed part of a store's total product and could therefore reveal something about the quality or integrity of the product and/or service offered. It is clear that the participants felt that a store that was too dark could portray an image of dirtiness and that the store was hiding something. They further emphasised the importance of the types of atmospheric elements used fitting in with the type of merchandise the store offered. Three quotes were taken from the focus groups to illustrate the participants' views on all three categories.

Three categories emerged from the second theme and are explained below.

Category 1: Store atmospherics spoke a silent language

The participants indicated that lighting which was too dark implied that the store was hiding something. The participants further stated that "warm" lighting portrayed an image of being more homey. It can therefore be inferred, from the focus group interviews, that when participants had a more positive connotation with the lighting, their chances of staying in the store were higher. Three quotes were taken from the focus group interviews which justify the findings:

- “... darkness implies they are hiding something. There is negativity to too much darkness that says, okay why? A, it's dirty, you know, they are hiding their quality, they are not proud to stand up and say something. I am just saying from a psychological perspective that is what darkness would imply."

- "Bright lighting conjures up feelings of openness and cleanliness."

- "Warm lighting will be more "homely."

Category 2: Store atmospherics could be context driven and therefore appeal to a specific target market or consumer group 
Both the focus group interviews and naïve sketches revealed that the participants felt the atmosphere of some stores was context driven and that it appealed to a specific niche or target market. When a participant did not feel comfortable in a store, sometimes due to bad lighting, they either did not enter the store or they left shortly after entering, as they did not feel welcome there.

The following two quotes of the participants were taken from both the focus group interviews and naïve sketches to validate the findings regarding the second category - context driven:

- $\quad$ "From a lighting perspective, I think lighting, to me personally, will, if I don't know the brand, if I am not familiar with that store at all, and it's very dark, I am going to be less inclined to go inside; but there is now an outside poll of a specific store, like the Marlboro Store or the Kingsley Heath stores or, that are creating a specific look ..."

- "When I go into a Zoot or one of these, I don't feel welcome anymore, the atmospherics is not right, I get the feeling it's the young people, the young people buy there and I feel that I am not welcome, but that is obviously not true. I just don't feel like the atmosphere is right, the music is too loud, lighting is not what I like, clothes are too cluttered, so I just, you know, me, I personally like the ambience of the stores that I frequent."

Category 3: Store atmospherics formed part of a store's total product

It was evident from both the focus group interviews and naïve sketches that the participants felt the types of atmospheric elements used formed part of the product and/or service offered by the store. In other words, the participants felt that the type of atmospherics used in a store should fit the type of merchandise offered. The participants further indicated that a dark store projected an image of poor quality and filthiness, whereas a store with proper lighting projected a feeling of cleanliness and good quality. It can therefore be inferred, from the focus group interviews and naïve sketches, that a more "elegant" store should make use of good lighting in order to emphasise the quality of the merchandise. The participants further pointed out that it was important for the type of music played in a store to fit in with the merchandise and services offered in order to contribute to the overall atmosphere of the store.

The following quotes of the participants were taken from both the focus group interviews and naïve sketches to confirm the above findings regarding the third category - store's total product:

- $\quad$ "too much darkness that says, okay why? ... it's dirty, you know, they are hiding their quality, they are not proud to stand up and say something. I am just saying from a psychological perspective that is what darkness would imply."

- "... darkness, to me, projects images of poor quality ..."

- $\quad$ "Cluttered, because I associate these modern stores mostly with the ... colours, clothing of questionable quality ..."

- "because of the lighting, is that it is clean, I get the feeling its clean, and that they are not hiding anything, that the quality is there."

Theme 3: $\quad$ Elements of store atmospherics that move towards either extreme (for example, too hot or too cold) become salient or obtrusive to consumers, leading to discomfort and limiting or disrupting browsing time and thus lessening the chance that the product will be discovered and bought.

The participants stated that certain atmospheric elements which moved towards the extremes; for instance, either too dark or too light, led to discomfort or irritation, which affected their spending. It was clear from both the focus group interviews and naïve sketches that the participants did not enter a store if they could see from a distance that the store was too dark. If the participants had, however, entered such a store, they would leave immediately if they recognised any unpleasant atmospheric elements.

The participants further indicated that unpleasant atmospheric elements decreased the likelihood that they would find something to buy, as the time spent on browsing was then immediately shortened. The participants stated 
that a store where the lighting was too dark would directly influence the amount of time spent in-store, which, in turn, affected their buying ability.

Two categories emerged from the second theme and are explained below.

Category 1: Atmospheric elements that moved towards the extremes, led to discomfort or irritation

The participants of both the focus group interviews and naïve sketches indicated that atmospheric elements which move towards an extreme in either direction led to irritation or discomfort and made them leave the store immediately. The participants would not enter a store if they observed from a distance that the lighting was too dark. Therefore, unpleasant atmospheric elements will most likely have a negative influence on the buying behaviour of consumers.

The following quotes of the participants were taken from both the focus group interviews and naïve sketches to confirm the above findings regarding the first category of elements that move to extremes:

- "With regards to lighting, I also think that, especially when you go into a store, if there are lights shining in your eyes, you feel uncomfortable, you want to get out of there as soon as possible ..."

- $\quad$ "I cannot make a decision in the dark."

- " "[lighting] influences whether you go into a shop or not, I mean a dark sort of dingy looking shop, you are not going to want to enter into, so it starts right at the outside of an appeal."

- " $\quad$ "[lighting] must be as close to the real thing as possible."

- $\quad$ "If the colours and lighting are unpleasant, it may cause me to decide to leave the store and go shop somewhere else, i.e. if the lights are too bright, flickering or not bright enough."

- $\quad$ "From a lighting perspective, I think lighting to me personally, will, if I don't know the brand, if I am not familiar with that store at all, and it's very dark, I am going to be less inclined to go inside ..."

Category 2: Unpleasant atmospheric elements decreased the likelihood that they would find something to buy

The participants in both the focus group interviews and naïve sketches explained that any unpleasant atmospheric element detected in the store, whether it was too dark or too light, had a direct influence on the amount of time that they spent browsing, which ultimately influenced the likelihood of purchasing something, most probably in a negative way. The participants made it clear that they would not tolerate any unpleasant atmospheric elements in-store and would therefore leave the store immediately. This would decrease the likelihood of buying something.

The following quotes of the participants were taken from both the focus group interviews and naïve sketches to validate the above findings regarding the second category - unpleasant atmospherics:

- “... will influence the time spent browsing and will influence whether I will try stuff on or not."

- $\quad$ "... but if the lighting is not, you know, to my appeal, then I am just going to spend less time there."

- “... I think it greatly has an impact on how long you spend in a store."

- " $\quad$... I am not going to stay there and spend time there."

\section{CONCLUSION}

The participants indicated that the lighting in a store was an important factor to them when considering whether to enter a store or not and when making a decision to purchase a product. It is clear from this that participants preferred a store to be immersed in light and not dark. If the participants observed from a distance that the lighting was too dark or not bright enough, it sometimes prevented them from entering the store, as they became irritated and felt that the quality of the products would not be good. The participants stated that a store that was too dark could easily be regarded as dirty and that the store was hiding something. It is therefore clear that lighting was very important to the participants. 
A well-lit store highlights the displayed merchandise better, making it easy for consumers to see and evaluate merchandise. This may influence them to stay longer in the store and improve their chances of buying.

The participants regarded lighting as a sign of cleanliness and quality and felt that correct lighting has the ability to guide consumers' in-store, enabling them to see all the merchandise, which may lead to unplanned purchases. It can be concluded that the type of lighting in a store will influence, or at least affect, the buying behaviour of consumers, depending on what they are looking for.

In summary, it was established that lighting has both a positive and a negative influence on consumers' buying behaviour in apparel retail stores in Tshwane. A positive influence means that consumers will stay longer in a store and will most likely spend more money, whereas a negative influence means that consumers will not enter a store or they will reduce the time that they spend in the store, thus influencing the possibility of sales negatively. The reasons for the positive and negative influence that lighting has on consumers' buying behaviour are:

- $\quad$ Consumers will not enter a store when they can observe from a distance that it is too dark. This has a direct negative influence on their buying behaviour.

- If consumers have entered a store and they cannot properly see, they will leave immediately as they get irritated. This has a negative influence on their buying behaviour.

- If the lighting in-store is good and correct, it will influence the total time spent in-store, which might lead to unplanned purchases. This influences their buying behaviour in a positive manner.

It is therefore critical that apparel retailers should give attention to the use of proper lighting in-store to ensure that the browsing time of consumers is increased.

\section{AUTHOR INFORMATION}

Corinne Nell is a lecturer in the Department of Marketing and Retail Management at the University of South Arica (UNISA). She worked in the retail sector in South Africa for many years and therefore developed an interest in retailing. Academic interests include retailing with a specific focus on Visual merchandising and store atmospherics, consumer behaviour, social media and consumers' perception. E-mail: nellec@unisa.ac.za

Professor Jan Wiid is a senior lecturer in the Department of Marketing and Retail Management at the University of South Africa. He has published 6 articles in refereed journals and is the editor and author of more than 5 books in marketing. These books are widely prescribed at universities in South Africa. He holds a DCom in Marketing from the University of Johannesburg. E-mail: jwiid@unisa.acza (Corresponding author)

\section{REFERENCES}

1. ACP Connections. (n.d.). Music and consumer behaviour. Retrieved 11-10-2011 from http://www.queenslandnewsagents.com.au/assets/images/MusicConsumerBehaviour.pdf

2. AR Dictionary. (2010). Sight. Retrieved 30-05-2012 from http://ardictionary.com/Sight/7431

3. Bell, J., \& Ternus, K. (2006). Silent selling. Best practice and effective strategies in visual merchandising (3rd ed.). New York: Fairchild.

4. Berman, B., \& Evans, J. R. (1998). Retail management: A strategic approach (7th ed.). New Jersey: Prentice-Hall.

5. Berman, B., \& Evans, J. R. (2010). Retail management: A strategic approach (11th ed.). New Jersey: Prentice-Hall.

6. Binggeli, C. (2010). Building systems for interior designers (2nd ed.). New Jersey: John Wiley \& Sons.

7. Braun, V., \& Clarke, V. (2006). Using thematic analysis in psychology. Qualitative Research in Psychology, 3, 77-101.

8. Collins. (2012). English Dictionary: Lighting. Retrieved 05-12-2012 from http://www.collinsdictionary.com/dictionary/english/lighting

9. Dunne, P. M., \& Lusch, R. F. (2008). Retailing (6th ed.). USA: Thomson South-Western. 
10. Eicar. (n.d.). Glossary: Lighting. Retrieved 05-12-2012 from http://www.eicarinternational.com/definition-lighting.html

11. Esaak, S. (2012). Art history: Colour. Retrieved 2012-04-12 from http://arthistory.about.com/cs/glossaries/g/c_color.htm

12. Gobé, M. (2009). Emotional branding: The new paradigm for connecting brands to people. New York: Allworth Press.

13. Gupta, S., \& Randhawa, G. (2008). Retail management. New Delhi: Atlantic.

14. Hair, J. F., Bush, R. P., \& Ortinau, D. J. (2009). Marketing research: In a digital information environment (4th ed.). Singapore: McGraw Hill.

15. Hultén, B. (2011). Sensory marketing: The multi-sensory brand-experience concept. European Business Review, 23(3), 256-273.

16. Hultén, B., Broweus, N., \& Van Dijk, M. (2009). Sensory marketing. London: Palgrave Macmillan.

17. Jang, S. S., \& Namkung, Y. (2009). Perceived quality, emotions and behavioural intentions: Application of an extended Mehrabian-Russell model to restaurants. Journal of Business Research, 62, 451-460.

18. Kang, E., Boger, C. A., Back, K. J., \& Madera, J. (2011). The impact of sensory environments on Spagoer's emotion and behavioural intention. Retrieved 10-07-2011 from

http://scholarworks.umass.edu/cgi/viewcontent.cgi?article=1115\&context=gradconf_hospitality

19. Kerfoot, S., Davies, B., \& Ward, P. (2003). Visual merchandising and the creation of discernible retail brands. International Journal of Retail \& Distribution Management, 31(3), 143-152.

20. Kotler, P. (2001). Atmospherics as a marketing tool. Journal of Retailing, 49(4), 48-64.

21. Levy, M., Weitz, B. A., \& Beitelspacher, L. S. (2012). Retailing management (8th ed.). New York: McGraw-Hill.

22. Liao, Y., \& Liaw, G. (n.d.). How cues in the multiple store environment influence shopping mood and patronage satisfaction. Retrieved 10-07-2011 from http://www.jimsjournal.org/8\%20Yen-Yi\%20Liao.pdf

23. Liaw, G. (2007). The influence of multiple store environment cues on shopping mood and patronage satisfaction. 7th Global Conference on Business \& Economics, ISBN: 978-0-9742114-9-4, pp. 1-21.

24. Liu, Y., \& Jang, S. S. (2009). The effects of dining atmospherics: An extended Mehrabian-Russell model. International Journal of Hospitality Management, 28, 494-503.

25. Mehrabian, A., \& Russell, J. A. (1974). An approach to environmental psychology. USA: The Colonial Press.

26. Morgan, T. (2008). Visual merchandising: Window and in-store displays for retail. China: Laurence King.

27. Pegler, M. M. (2010). Visual merchandising and display (5th ed.). China:Fairchild.

28. Pradhan, S. (2007). Retailing management: Text and cases (2nd ed.). Nagar, New Delhi: Tata McGrawHill.

29. Spies, K., Hesse, F., \& Loesch, K. (1997). Store atmosphere, mood and purchasing behaviour. International Journal of Research in Marketing, 14, 1-17.

30. Tesch, R. (1990). Qualitative research analysis tapes and software tools. New York: Wordsworth.

31. The Free Dictionary. (2012). Lighting. Retrieved 05-12-2012 from http://www.thefreedictionary.com/lighting

32. Tustin, D. H., Ligthelm, A. A., Martins, J. H., \& Van Wyk, H. de J. (2005). Marketing research in practice. Pretoria: Unisa Press.

33. Wanninayake, W. M. C. B., \& Randiwela, P. (2007). The impact of visual merchandising on consumer store choice decisions in Sri Lankan supermarkets. 7th Global Conference on Business \& Economics, ISBN: 978-0-9742114-9-4, pp. 1-16.

34. Zikmund, W. G., \& Babin, B. J. (2007). Exploring marketing research (3rd ed.). Mason: Thomson SouthWestern.

35. Zikmund, W. G., Babin, B. J., Carr, J. C., \& Griffin, M. (2010). Business researched methods (8th ed.). Canada: South-Western Cengage Learning. 